\title{
Virulent Aeromonas veronii Strain BLB-01 Associated with Mass Mortality of Clarias batrachus (Linnaeus, 1758)
}

\section{Arun Sharma ${ }^{1 *}$, Thongam Ibemcha Chanu ${ }^{1}$, Muralidhar P. Ande ${ }^{2}$, P. P. Suresh Babu ${ }^{3}$, Karthireddy Syamala ${ }^{2}$, Pothu Srinivasa Rao ${ }^{2}$, Ashutosh D. Deo ${ }^{4}$ and Shrinivas Jahageerdar ${ }^{4}$}

${ }^{1}$ ICAR-Central Institute of Fisheries Education, Kakinada Centre FWFF, Balabhadrapuram, Andhra Pradesh-533007, India

${ }^{2}$ ICAR-Central Institute of Fisheries Education, Kakinada Centre, Beach Road,

Kakinada, Andhra Pradesh-533007, India

${ }^{3}$ ICAR-Central Marine Fisheries Research Institute, Kochi, India

${ }^{4}$ ICAR-Central Institute of Fisheries Education, Panch Marg, Off Yari Road, Mumbai-400061, India

*Corresponding author

\section{A B S T R A C T}

Keywords

Clarias

batrachus,

Aeromonas

veronii,

Mass mortality,

Virulence test.

Article Info

Accepted:

27 June 2017

Available Online:

10 August 2017
The Asian catfish, Clarias batrachus of the family claridae, commonly known as 'magur' has high commercial importance in India. Aeromonas veronii has been reported as an important bacterial pathogen for aquatic animals and humans. Several reports have demonstrated the pathogenic effect of other Aeromonas species on aquatic animal; however in farmed $C$. batrachus no definitive data are available about $A$. veronii infection. In the present study, a virulent $A$. veronii strain BLB-01was isolated from the infected $C$. batrachus collected from freshwater fish farm Balabhadrapuram, East Godavari district, Andhra Pradesh, India and its identification was confirmed by $16 \mathrm{~S}$ rRNA amplification and sequencing (Gen Bank accession number.MF370515). In addition two genes encoding aerolysin (aerA), haemolysin $(h l y A)$ were found present in the isolate which further confirmed its potential virulence. Histologically, the infected muscle tissue showed erythrocyte and leukocyte infiltration due to bacterial infection. In vitro antimicrobial susceptibility test was also conducted by using effective antibiotic drugs to guide the treatment of the disease.

\section{Introduction}

The Asian catfish, Clarias batrachus, (Linnaeus, 1758) commonly known as 'magur', are one of the most widespread catfish genera, found in inland waters in most part of the world (Thomas et al., 2013). It is one of the most popular and economically important indigenous freshwater food fishes in the countries like India, Bangladesh, Sri Lanka, Myanmar and Malaysia (Argungu et al., 2013; Mookerjee and Mazumder, 1950). C. batrachus culture has high commercial importance in India and it has been identified 
as one of the potential national priorities in Indian aquaculture (Paul et al., 2015). Aeromonas species are ubiquitous inhabitants in nature and increasingly being reported as important pathogen for both human and lower vertebrates, including fish (Janda and Abbott, 1998). Motile aeromonads have been associated with mass mortalities of fish around the globe and consider as the most common and troublesome diseases of warm and cold water fish, resulting in huge economic losses (Janda and Abbott, 2010; Paul et al., 2015). Many reports demonstrated that Aeromonas salmonicida, Aeromonas hydrophila, Aeromonas caviae and Aeromonas sobria were frequently occurring species of Aeromonas that have been considered important in fish pathology (Janda and Abbott, 2010; Paul et al., 2015).

Recently, the panorama of species has been expanded with the discovery of many new Aeromonas species (Martinez et al., 2013). Among them A. veronii has been described as an important fish and human pathogen (Singh et al., 2012). A. veronii pathogen has been isolated from Ichtalurus punctatus (Nawaz et al., 2006), Coilisa lalia (Hossain, 2008), Misgurnus anguillicaudatus (Qin et al., 2008), Acipenser baerii (Ma et al., 2009), Cyprinus carpio (Gong et al., 2010), Ictalurus lunetas (Huang et al., 2010), Leiocassis longirostris Gunther (Cai et al., 2012), Astronotus ocellatus (Sreedharan et al., 2011), Oreochromis niloticus (Eissa et al., 2015), Channel catfish, Ictalurus punctatus (Liu et al., 2016) and Carassius gibelio (Sun et al., 2016). However, there is no definitive data on pathogenic association of $A$. veronii infection in cultured $C$. batrachus.

In this paper, in order to investigate the cause of the disease, a virulent $A$. veronii strain could be isolated from the infected $C$. batrachus at freshwater fish farm Balabhadrapuram, East Godavari district,
Andhra Pradesh, India and confirm the etiology through phenotypic, molecular characterization and histopathological alterations caused by the bacteria.

\section{Materials and Methods}

\section{Isolation and phenotypic characterization of bacteria from $C$. batrachus}

The moribund Clarias batrachus samples were collected from three culture ponds at freshwater fish farm Balabhadrapuram, East Godavari district of Andhra Pradesh. Where affected fish had developed similar pathological signs and almost $60 \%$ of the animal died. The infected fish swam slowly on the surface of the water and had different degrees of ulcer, fin rot. 20 no's of infected fish samples were aseptically transported to laboratory within one hour using sterile plastic bag containing aerated water (water temperature $26 \pm 2.0^{\circ} \mathrm{C}$ ). The physicochemical parameters viz. dissolve oxygen (DO), $\mathrm{pH}$ and water temperature were analyzed during sampling in the infected pond following standard procedure. The dissolved oxygen was analyzed by the Winkler method (APHA, 2005). Fish muscle and kidney were used for microbial examination. The infected fish with typical clinical signs were sanitized with $75 \%$ alcohol and the bacteria were isolated from muscle and kidney under aseptic condition. The specimens were inoculated onto nutrient agar (Himedia, India); tryptone soya agar supplemented with $0.5 \% \mathrm{NaCl}$ (Himedia, India) and brain heart infusion agar (Himedia, India) plate and incubated aerobically for $24 \mathrm{~h}$ at $28^{\circ} \mathrm{C}$ and further observed upto $48 \mathrm{~h}, 72 \mathrm{~h}$ and $96 \mathrm{~h}$ at $28^{\circ} \mathrm{C}$. After incubation, the dominant colony on nutrient agar, tryptone soya agar and brain heart infusion agar were re-streaked onto the respective agar media to obtain pure isolate. Colonies of different shape and sizes were chosen for Gram staining. All the purified 
isolates were stored on nutrient agar slants and tryptone soya agar slants at $4^{\circ} \mathrm{C}$ for later use and maintained frozen in nutrient broth (Himedia, India) and tryptic soy broth (Himedia, India) with $20 \% \quad(\mathrm{v} / \mathrm{v})$ sterile glycerol at $-20^{\circ} \mathrm{C}$. The phenotypic characterization involve morphological and biochemical tests were performed according to the methodologies described by Bergey's Manual of Systematic Bacteriology (Vos et al., 2009) and HIIMVIC biochemical test kit, Himedia India. The tests include Gram staining, motility, Oxidase test, Catalase test, Voges- proskauer test, Nitrate reduction, citrate utilization, Indole production, Arginine dihydrolase, O/129 sensitivity, Trehalose, Mannose, D-Ribose, Mannitol, Ornithine decarboxylase, Esculine hydrolysis, Lactose, $6.5 \%$ Sodium chloride, Urease, Sorbitol, Inulin, Arabinose, Raffinose, Methyl-red, Oxidation of ONPG, carbohydrate fermentation etc.

\section{Molecular characterization of the isolated bacteria}

The culture isolate were subjected to molecular analyses in order to compare and test the phenotypic determination. The genomic DNA was extracted from the isolated bacteria using uniflex DNA isolation kit (Himedia, India) as per manufacturer's protocol. The 16S rRNA gene was amplified by PCR using universal primers 27F, 5'-AGA GTT TGA TCC TGG CTC AG-3' and 1541R, 5'-AAG GAG GTG ATC CAG CCG CA-3' (Zhang et al., 2011).

The nucleotides of the 16S rRNA sequence were matched with the other microbes in the database of National Centre for Biotechnology Information (NCBI) using the programme Basic Local Alignment Search Tool (BLAST). The evolutionary history was inferred using the Neighbor-Joining method. The evolutionary distances were computed using the Maximum Composite Likelihood method. The analysis involved 9 nucleotide sequences. All positions containing gaps and missing data were eliminated. There were a total of 1480 positions in the final dataset. Evolutionary analyses were conducted using MEGA7 software.

\section{Virulence gene assay}

The genomic DNA was extracted from the pure cultures using a uniflex DNA isolation kit following the instructions of the manufacturer (Himedia, India). Two virulence genes encoding aerolysin (aerA), haemolysin (hlyA) were respectively amplified by PCR using specific aerA, hlyA gene primers (Table 1) as recommended by Kong et al., (2002), Wong et al., (1998). PCR amplification of virulence genes was carried out in a reaction volume of $25 \mu \mathrm{l}$ by using a Hi-PCR Kit (Himedia, India). The final concentrations in the PCR mixture were 2x Taq PCR master Mix $12.5 \mu \mathrm{L}, 0.5 \mu \mathrm{L}$ forward and $0.5 \mu \mathrm{L}$

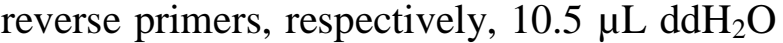
and $1 \mu \mathrm{L}$ DNA as template. The thermal cycling conditions were optimized as an initial denaturation at $95^{\circ} \mathrm{C}$ for $5 \mathrm{~min}$ followed by a total of 35 cycles of denaturation at $95^{\circ} \mathrm{C}$ for $1 \mathrm{~min}$, annealing at $55^{\circ} \mathrm{C}$ for $1 \mathrm{~min}$ and extension at $72^{\circ} \mathrm{C}$ for $1 \mathrm{~min}$. The final extension was done at $72^{\circ} \mathrm{C}$ for $10 \mathrm{~min}$. A reagent blank except template DNA for which sterile distilled water was used. The PCR products were electrophoresed on $1 \%$ agarose gel stained with ethidium bromide $(1 \mathrm{mg} / \mathrm{mL})$ and visualized through ultraviolet transillumination. A 50-bp DNA ladder was used as the size standard.

\section{Pathogenicity of isolated $A$. veronii strain BLB-01 on C. batrachus}

To study the virulence of the bacterial pathogen, a challenge study was conducted in healthy $C$. batrachus using the bacteria 
Aeromonas veronii strain BLB-01 isolated from the infected $C$. batrachus. $C$. batrachus weighing approximately $70 \pm 2.22 \mathrm{~g}$ were maintained in FRP tubs (100 L capacity) for 15 days in order to adapt to laboratory conditions at $26-28^{\circ} \mathrm{C}$.

All fishes were anaesthetized with clove oil (Himedia, India) and then injected (intramuscular injection) with $0.1 \mathrm{~mL}$ bacterial suspensions ( $24 \mathrm{~h}$ bacterial culture, $10^{4}-10^{8}$ CFU/fish).

The $\mathrm{LD}_{50}$ tests were conducted with batches of 10 fish/dose following Reed and Muench (1938). Sterile PBS was injected into other group of fish as parallel controls. The challenged fish were observed daily for pathological signs and mortalities were recorded for 15 days post injection with bacterial inoculum. The dead fish were processed for bacterial analyses in all the cases.

\section{Histopathology}

The muscle tissue of infected $C$. batrachus was fixed in $10 \%$ neutral buffer formalin solution and then embedded in paraffin wax following standard techniques. Tissue sections in $5 \mu \mathrm{m}$ width were stained with haematoxylin and eosin according to Roberts, 2012.

\section{In vitro antimicrobial susceptibility test}

In vitro antimicrobial susceptibility testing was performed followed by disk diffusion method of Kirby-Bauer (Bauer et al., 1996). All filter-paper discs were obtained from Himedia, India. After $24 \mathrm{~h}$ of incubation at $28^{\circ} \mathrm{C}$ the zones of inhibition were measured. The isolates were classified as resistant (R), moderately sensitive $(\mathrm{M})$ and sensitive $(\mathrm{S})$ on the basis of the size of the zone of inhibition described by the National Committee for Clinical Laboratory Standards (2000).

\section{Results and Discussion}

\section{Isolation and phenotypic characterization of bacteria from C. batrachus}

At the beginning stage of the disease, the fish have a low mortality. Infected fish were lethargic and swam along the surface of the pond. The principle clinical signs of the affected $C$. batrachus were fin rot and ulcerated red area on body surface (Fig. 1. a, b) and deep skin ulcers on different side of the body surface become noticeably visible (Fig.1 c, d). At later stage of infection fish stop feeding and died, mortality was recorded up to $60 \%$.

The range of physico-chemical parameters of all the three pond water viz. temperature (26 $\left.30^{\circ} \mathrm{C}\right), \mathrm{pH}(6.5-7.0)$ and dissolved oxygen (4.3-5.5 mg/L) were reported. After $24 \mathrm{~h}$ of incubation under aerobic conditions, colonies appeared on the nutrient agar, tryptone soya agar and brain heart infusion agar plate.

The colonies were round or ellipse in shape with 1-3 $\mathrm{mm}$ diameter size in all the media and creamy white color in nutrient agar; colorless, transparent, smooth in tryptone soya agar; white color in brain heart infusion agar. After $48 \mathrm{~h}, 72 \mathrm{~h}$ and $96 \mathrm{~h}$ incubation at $28^{\circ} \mathrm{C}$ only one type of dominant colony was observed in all the plates.

All the colonies were tested by Gram's staining method and viewed under a microscope and same type of gram-negative bacillus was isolated from the diseased fish as identified with biochemical and phenotypic analysis (Fig. 2).

The phenotypic identification protocol revealed that, the suspected micro biota was Gram negative, motile bacteria. The strain were positive for Oxidase test, Catalase test, Voges- proskauer test, Oxidation of ONPG, Nitrate reduction, citrate utilization, Lysine 
decarboxylase, Indole production, Arginine dihydrolase, O/129 sensitivity, Trehalose, Mannose, D-Ribose, Mannitol. The strain were negative for Ornithine decarboxylase, Esculine hydrolysis, Lactose, 6.5\% Sodium chloride, Urease, Sorbitol, Inulin, Arabinose, Raffinose, Methyl-red. The strain had the ability to ferment carbohydrate. Based on the morphological and biochemical test the suspected strain was presumed as $A$. veronii (Table 2).

The bacteria $A$. veronii belongs to genus Aeromonas and it was first reported by Hichman-Brenner et al., (1987). It usually infects human beings and causes diseases like septic arthritis, bacteremia, spontaneous bacterial empyema and severe pneumonia (Wang et al., 2000; Roberts et al., 2006; Li et $a l ., 2008)$. It has been seen that, $A$. veronii not only infect human being but also infects fish to spread diseases quickly (Huang et al., 2010).

\section{Molecular characterization and phylogeny of the isolated bacteria}

NCBI blast search analysis confirmed that, the isolated bacteria were $A$. veronii strain BLB-01. The PCR products of $16 \mathrm{~S}$ rRNA were about 1500 bp after an Agarose gel electrophoresis was run (Fig. 3) and it was demonstrated that the $16 \mathrm{~S}$ rRNA PCR products were $1480 \mathrm{bp}$ by sequencing.

Phylogenetic and evolutionary analysis of the $16 \mathrm{~S}$ rRNA sequence revealed that, the Aeromonas veronii strain BLB-01shared at 99-100 \% similarity to other $A$. veronii strain (Fig. 4). The sequence were deposited in NCBI database, the strain name and gene bank accession number were Aeromonas veronii strain BLB-01; MF370515. Phylogenetic analysis based on the $16 \mathrm{~S}$ rRNA gene is universally used and considered as an appropriate tool for the reconstruction of evolutionary history and phylogenetic relationship of bacterial genera (Stackebrandt and Goebel, 1994). In the present study, all the sequences of $16 \mathrm{~S}$ rRNA gene from the representative isolated bacterial strain $A$. veronii strain BLB-01 showed high similarity (99-100 \%) with other Aeromonas spp.in the GenBank database (NCBI) confirming $A$. veronii strain BLB-01 was the responsible pathogen for mortality in $C$. batrachus at freshwater fish farm Balabhadrapuram, Andhra Pradesh, India.

\section{Virulence gene assay}

The specific virulence gene aerA and hlyA fragments were obtained with the $A$. veronii strain BLB-01 using a pair of aerA-specific primers (720 bp region) and $h l y A$ specific primers (597 bp region) respectively (Fig. 4) provide a direct way to manifest the virulence of the bacterial strain in farmed C. batrachus as these genes are closely related with the pathogenicity of Aeromonas species (Sun et al., 2016). Moreover, the virulence factor genes are also considered as good markers for identifying the microorganism pathogenicity (Sun et al., 2016). Wilmsen et al., (1990) reported aerolysin can leads to cell lysis through the oligomerization process and forming channels in the cell membrane. The production of haemolytic toxins (hlyA and aerA) provides a strong evidence of aeromonads potential pathogenicity (Santos et al., 1999).

\section{Pathogenicity of Aeromonas veronii strain BLB-01 on C. batrachus}

Challenged with the bacterial suspensions of A.veronii strain BLB-01into C. batrachus was lethal to the fish, in comparison to the control groups injected with sterile PBS. The $\mathrm{LD}_{50}$ of the strain live cells for $C$. batrachus was about $3.14 \times 10^{6} \mathrm{CFU} /$ fish in intramuscular injection (Table 3). The moribund or dead fish exhibited the same signs as the diseased fish on ulcerative condition in the ponds. 
Table.1 PCR primers, targets, amplicon sizes used in the study

\begin{tabular}{llllll}
\hline Sl. no. & Name of gene & Primer sequence (5'-3') & Product size (bp) & Length (bp) & Reference \\
\hline 1. & aeroA & Aero-F TGTCGGSGATGACATGGAYGTG & 720 & 22 & Kong et \\
& & Aero-R CCAGTTCCAGTCCCACCACTTCA & & 23 & al., 2002 \\
2. & \multirow{2}{*}{ hlyA } & hlyA-F GGCCGGTGGCCCGAAGATACGGG & 597 & 23 & Wong et \\
& & hlyA-R GGCGGCGCCGGACGAGACGGG & & 21 & al., 1998 \\
\hline
\end{tabular}

Table.2 Phenotypic identification of A. veronii strain BLB-01 form farmed C. batrachus

\begin{tabular}{lll}
\hline Sl. No. & Test items & Reaction \\
\hline 1. & Gram's staining & $-\mathrm{ve}$ \\
2. & Motility & $+\mathrm{ve}$ \\
3. & Voges- proskauer & $+\mathrm{ve}$ \\
4. & Oxidation of ONPG & $+\mathrm{ve}$ \\
5. & Oxidase & $+\mathrm{ve}$ \\
6. & Catalase & $+\mathrm{ve}$ \\
7. & Trehalose & $+\mathrm{ve}$ \\
8. & Nitrate & $+\mathrm{ve}$ \\
9. & O/F test & Fermentative \\
10. & Lysine & $+\mathrm{ve}$ \\
11. & Arginine & $+\mathrm{ve}$ \\
12. & Mannose & $+\mathrm{ve}$ \\
13. & Bile esculine 40\% & $-\mathrm{ve}$ \\
14. & Lactose & $-\mathrm{ve}$ \\
15. & 6.5\% Sodium chloride & $-\mathrm{ve}$ \\
16. & D-Ribose & $+\mathrm{ve}$ \\
17. & Ornithine & $-\mathrm{ve}$ \\
18. & Simmons citrate & $+\mathrm{ve}$ \\
19. & Urease & $-\mathrm{ve}$ \\
20. & Sorbitol & $-\mathrm{ve}$ \\
21. & Inulin & $-\mathrm{ve}$ \\
22. & Indole & $+\mathrm{ve}$ \\
23. & Mannitol & $+\mathrm{ve}$ \\
24. & Arabinose & $-\mathrm{ve}$ \\
25. & Raffinose & $-\mathrm{ve}$ \\
26. & Methyl-red & $-\mathrm{ve}$ \\
27. & O/129 sensitivity & $+\mathrm{ve}$ \\
\hline
\end{tabular}

Table.3 Pathogenicity tests of isolated A. veronii strain BLB-01 intramuscularly injected into $C$. batrachus during 15 days observation

\begin{tabular}{|c|c|c|c|c|c|c|c|}
\hline \multirow[t]{2}{*}{$\begin{array}{l}\text { Dilution of } \\
\text { bacterial } \\
\text { culture }\end{array}$} & \multicolumn{2}{|c|}{$\begin{array}{l}\text { Number of death } \\
\text { and live fish during } \\
15 \text { d period of } \\
\text { observation }\end{array}$} & \multirow[t]{2}{*}{$\begin{array}{l}\text { Cumulative } \\
\text { live fish }\end{array}$} & \multirow[t]{2}{*}{$\begin{array}{l}\text { Cumulative } \\
\text { death in fish }\end{array}$} & \multirow[t]{2}{*}{$\begin{array}{l}\text { Mortality } \\
\text { ratio }\end{array}$} & \multirow[t]{2}{*}{$\begin{array}{l}\text { \% of } \\
\text { mortality }\end{array}$} & \multirow[t]{2}{*}{$\begin{array}{l}\text { LD }_{50} \text { value } \\
\text { (CFU fish } \\
\text { (1) }\end{array}$} \\
\hline & Live & dead & & & & & \\
\hline $10^{4}$ & 0 & 10 & 0 & 29 & $29 / 29$ & 100 & \\
\hline $10^{5}$ & 3 & 7 & 3 & 19 & $19 / 22$ & 86.36 & \\
\hline $10^{6}$ & 7 & 3 & 7 & 10 & $10 / 20$ & 50 & \\
\hline $10^{7}$ & 9 & 1 & 19 & 3 & $3 / 22$ & 13.63 & $3.14 \times 10^{6}$ \\
\hline $10^{8}$ & 10 & 0 & 29 & 0 & $0 / 29$ & 0 & \\
\hline $\begin{array}{l}\text { Control } \\
\text { (PBS) }\end{array}$ & 10 & 0 & - & - & - & & \\
\hline
\end{tabular}


Table.4 Sensitivity of the isolated A. veronii strain BLB-01 to various antimicrobial agent

\begin{tabular}{lcc}
\hline Antimicrobial & MIC $^{*}\left(\boldsymbol{\mu} \mathbf{g m I}^{-1}\right)$ & Sensitivity $^{\#}$ \\
\hline Cephalothin & $\leq 8$ & $\mathrm{R}$ \\
Chloramphenicol & $\leq 8$ & $\mathrm{~S}$ \\
Ciprofloxacin & $>2$ & $\mathrm{R}$ \\
Clarithromycin & $>4$ & $\mathrm{R}$ \\
Clindamycin & $>2$ & $\mathrm{R}$ \\
Erythromycin & 4 & $\mathrm{M}$ \\
Fosfomycin & $\leq 32$ & $\mathrm{~S}$ \\
Fusidic Acid & 16 & $\mathrm{M}$ \\
Gentamicin & $\leq 4$ & $\mathrm{~S}$ \\
Levofloxacin & 4 & $\mathrm{R}$ \\
Moxifloxacin & $>1$ & $\mathrm{R}$ \\
Netilmicin & $\leq 8$ & $\mathrm{~S}$ \\
Oxacillin & $>2$ & $\mathrm{R}$ \\
Rifampin & $\leq 1$ & $\mathrm{~S}$ \\
Synercid & $>2$ & $\mathrm{R}$ \\
Teicoplanin & $>16$ & $\mathrm{R}$ \\
Tetracycline & 8 & $\mathrm{M}$ \\
Vancomycin & $>16$ & $\mathrm{R}$ \\
\hline
\end{tabular}

*MIC-Minimum Inhibitory Concentration; ${ }^{\#}$ R-resistance; S-sensitive; M-moderately sensitive

Fig.1 Bacterial infection caused by Aeromonas veronii in farmed Clarias batrachus.

(a) Infected fish showing fin rot and ulcerated red area on body surface.

(b) A stock of fish showing fin rot and ulcerated red area on body surface.

(c) \& (d) Deep skin ulcers on different side of the body surface become noticeably visible
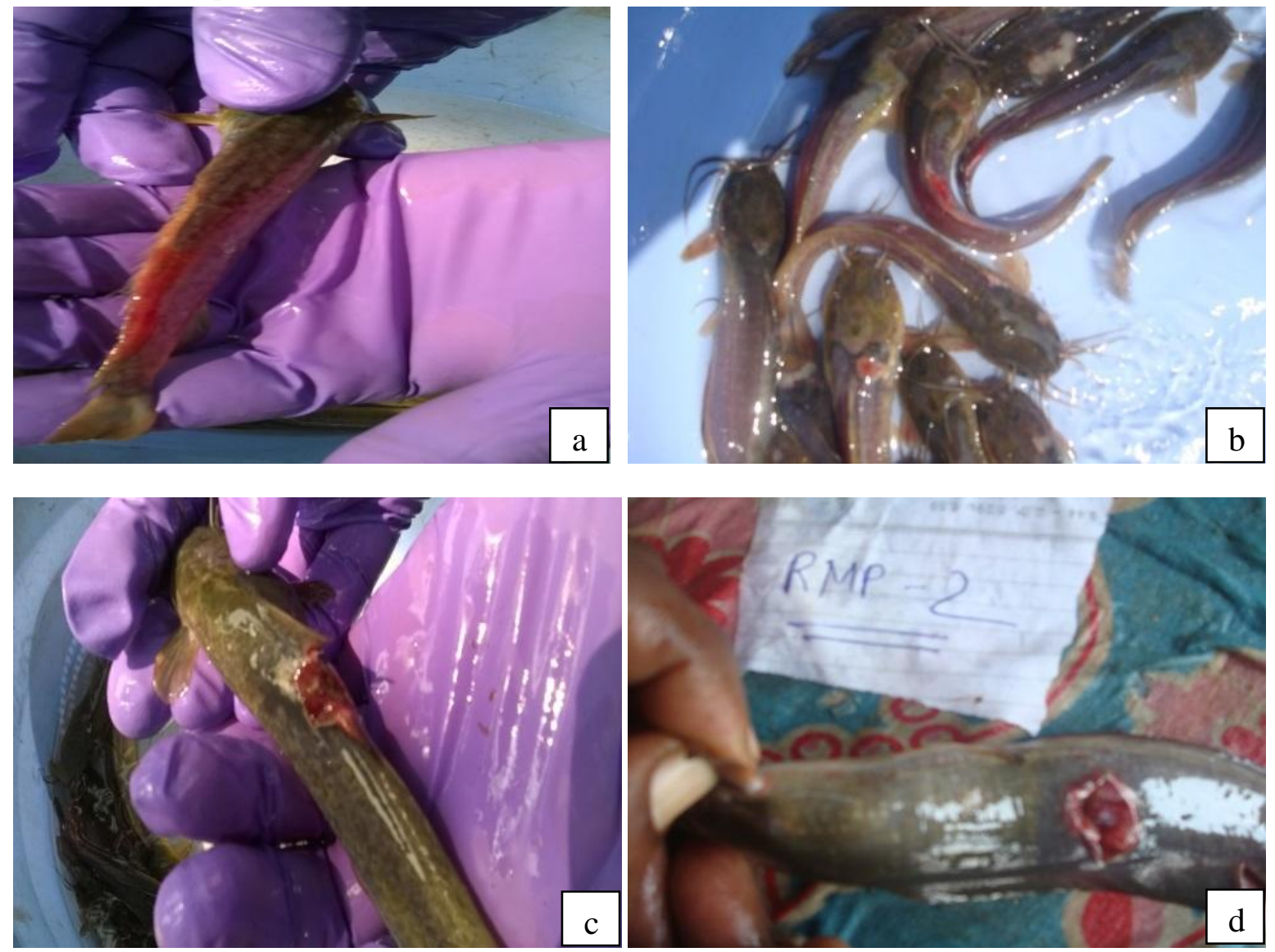
Fig.2 Typical morphology of a gram negative bacilli Aeromonas veronii

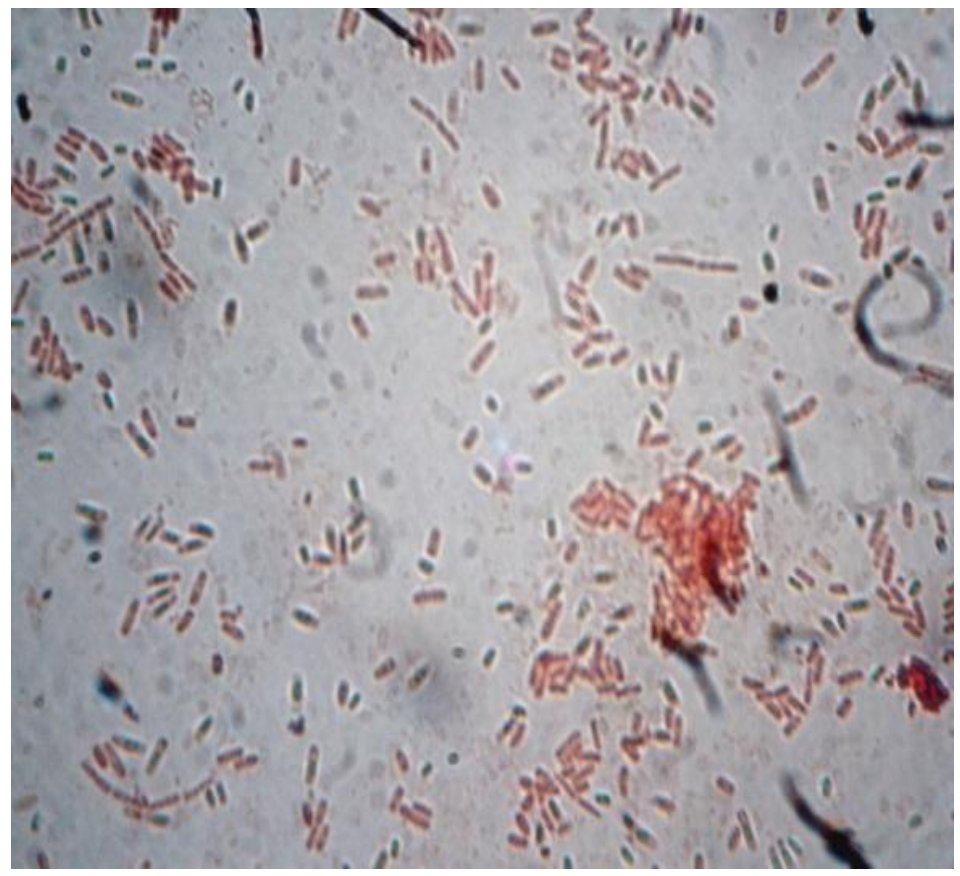

Fig.3 PCR amplified product with 16S rRNA oligonucleotide primer. Lane 1: ladder, lane 2: amplification of $1500 \mathrm{bp}$ product from the template DNA

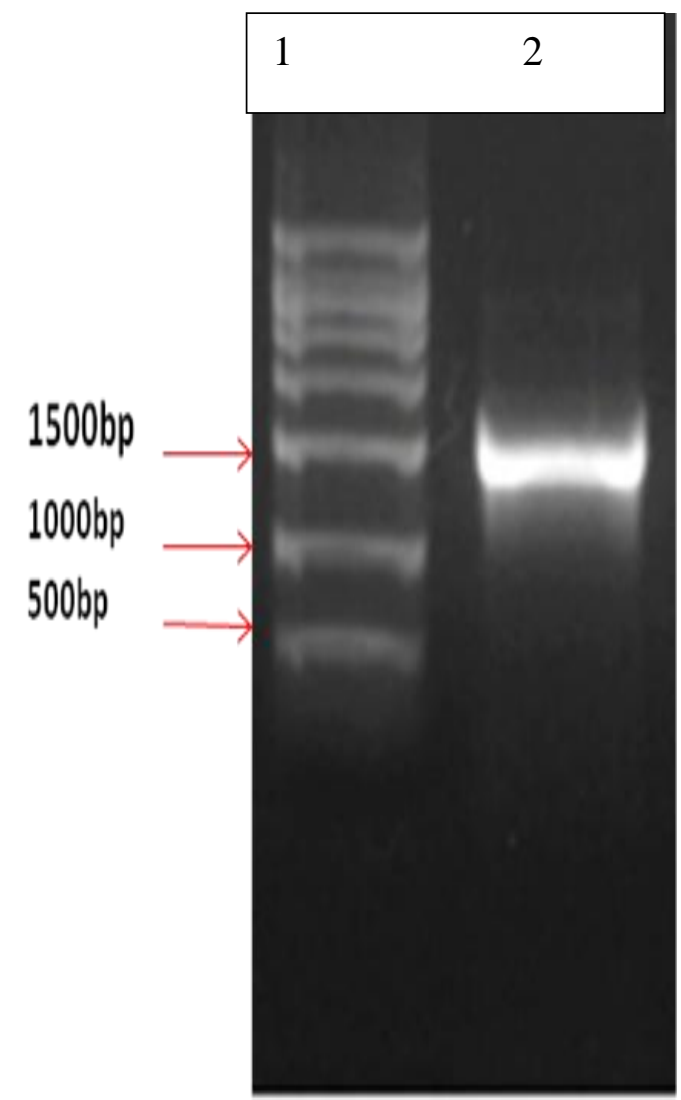


Fig.4 Nucleotides homology and phylogenetic analysis of the microbe based on 16S rRNA gene sequence data compare with other $A$. veronii in the database

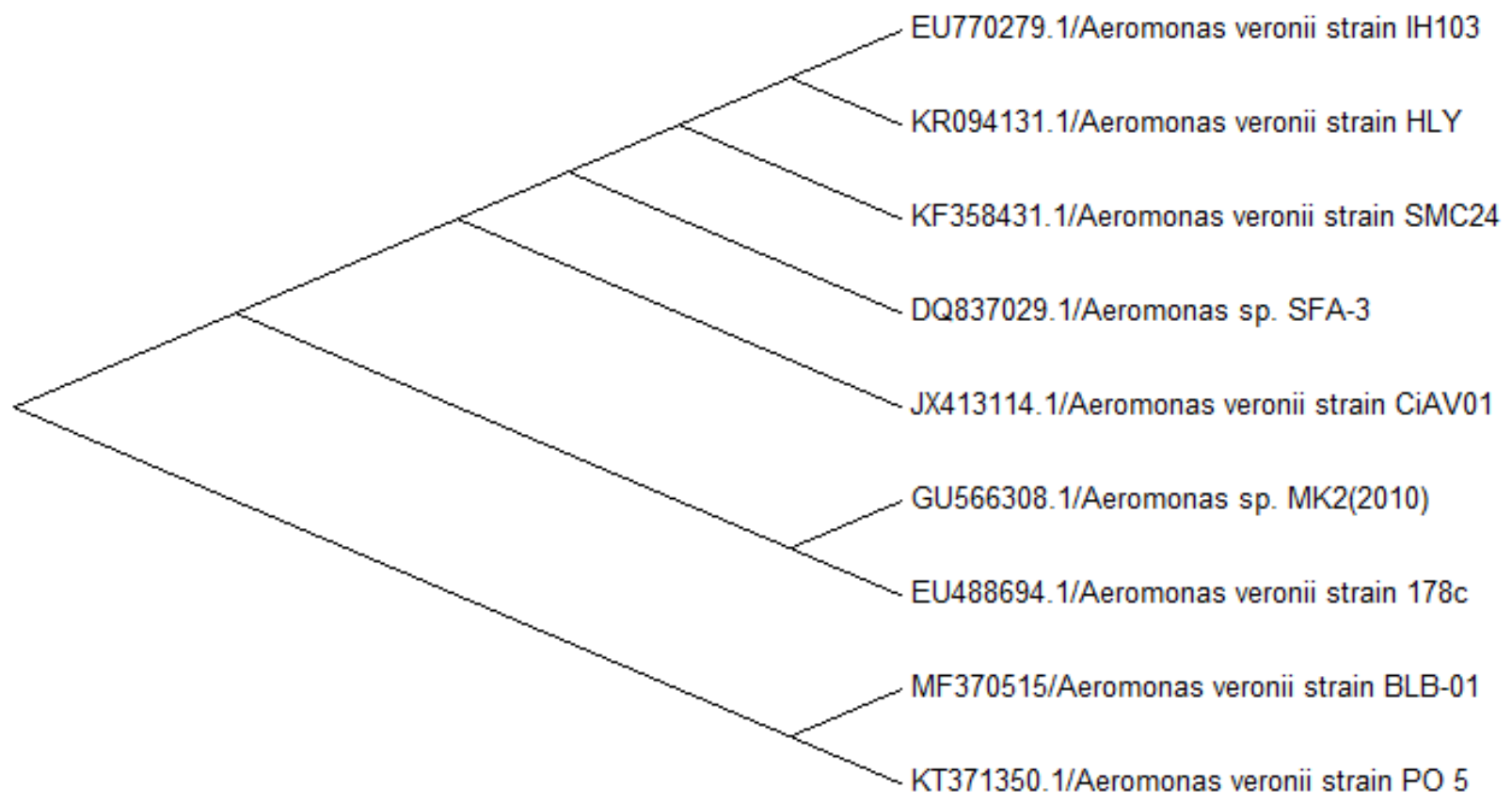

Fig.5 A-B: (A) lane-1: amplification of the 720-bp region of the aerA gene from the template DNA, lane-2: -ve control and lane-3: 50-bp DNA ladder. (B) Lane-1: 50 bp DNA ladder, lane-2: amplification of the 597-bp region of the hlyA gene and lane-3: -ve control

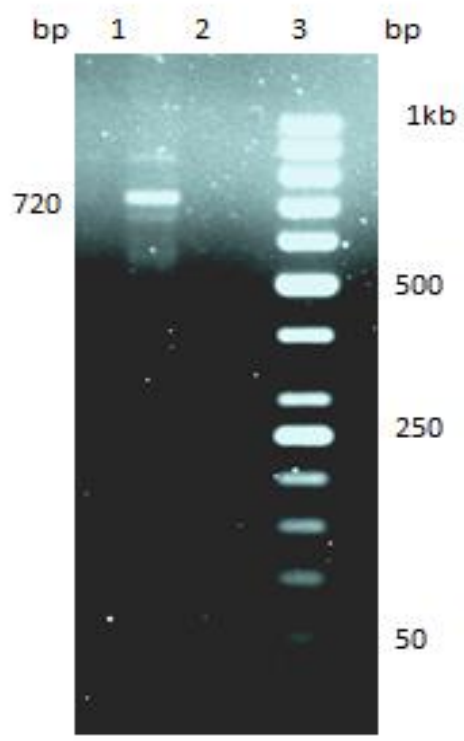

A

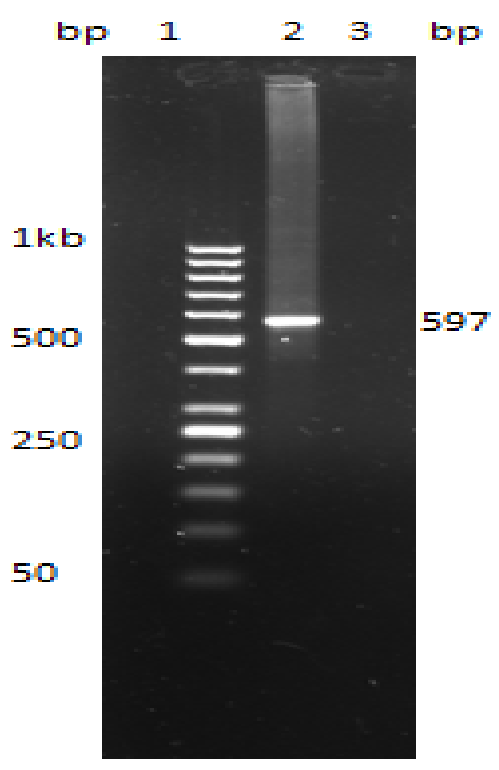

R 
Fig.6 Histological details of the ulceration of the connective tissues: (a) Erythrocyte and leukocyte infiltration (ELI) in the connective tissue of fish muscle due to bacterial infection (X10). (b) Erythrocyte (E) and lymphocytic infiltration (L) (X100). (c)Monocyte and erythrocyte infiltration (X100). (d) Neutrophil and erythrocyte infiltration(X100). H\&E staining
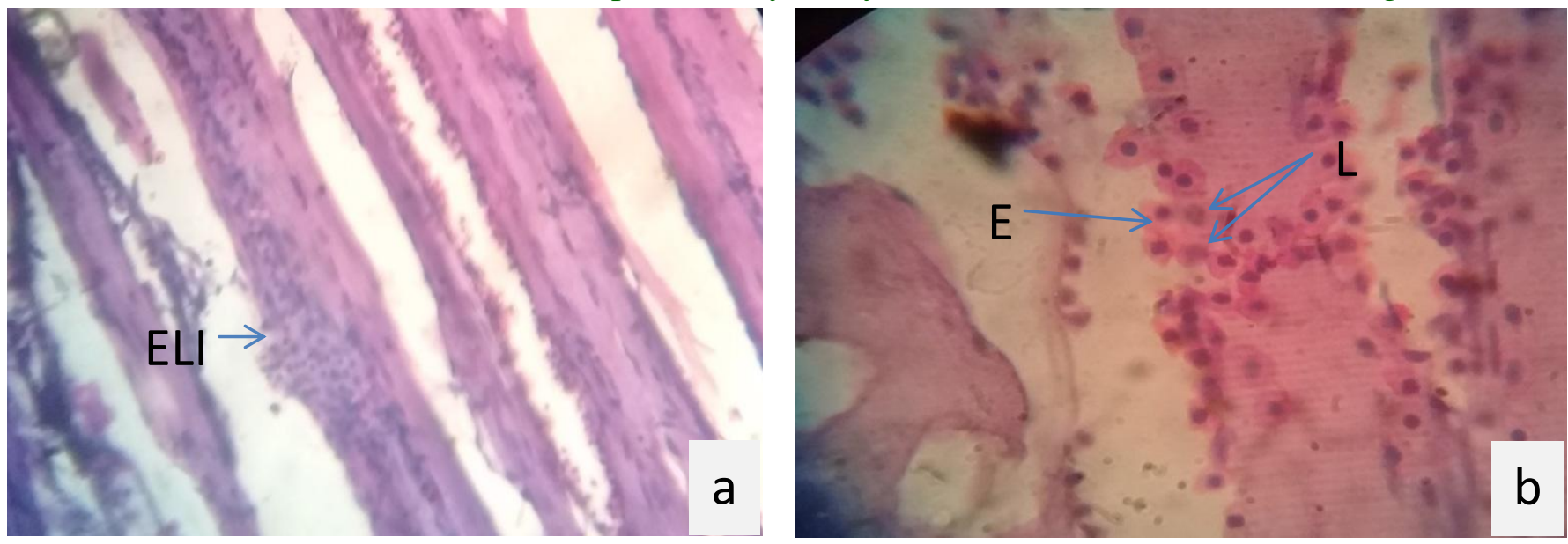

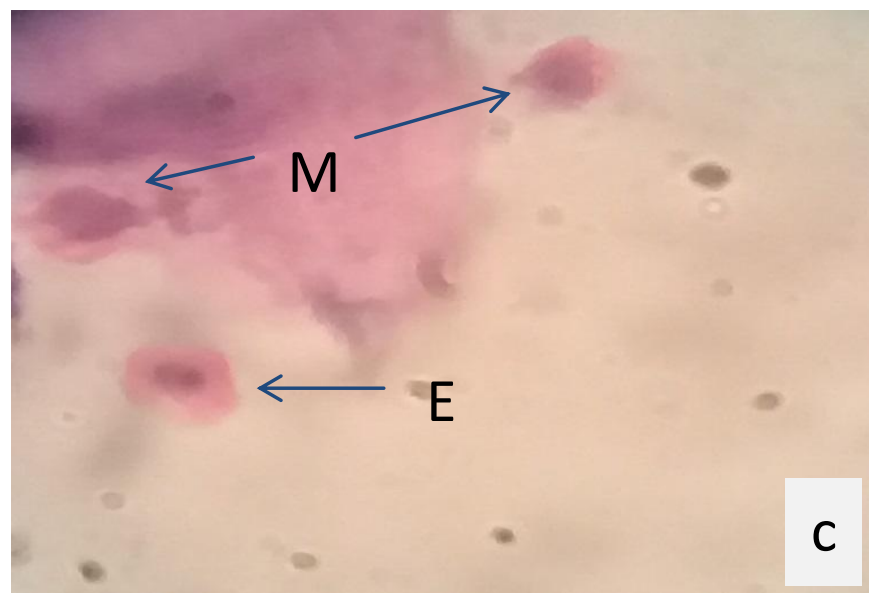

The pathogenic capacity of the strain has been verified by fulfillment of Koch's postulates. Han et al., (2008), reported that A. veronib v. veroni strain RY001 was virulent to goldfish with an $\mathrm{LD}_{50}$ value of $1.6 \times 10^{6} \mathrm{CFU} /$ fish which was also in line with the present strain. Cai et al., (2012), reported that A. veronibv. veroni strain PY50 was virulent in Chinese long snout catfish when injected intraperitoneally with an $\mathrm{LD}_{50}$ value of $3.47 \times 10^{4} \mathrm{CFU} /$ fish which is much lower compared to the present strain. The i.p. administered median lethal dose values ranged from $5 \times 10^{3}-5.2 \times 10^{9} \mathrm{CFU} /$ fish in gilthead sea bream challenge against several

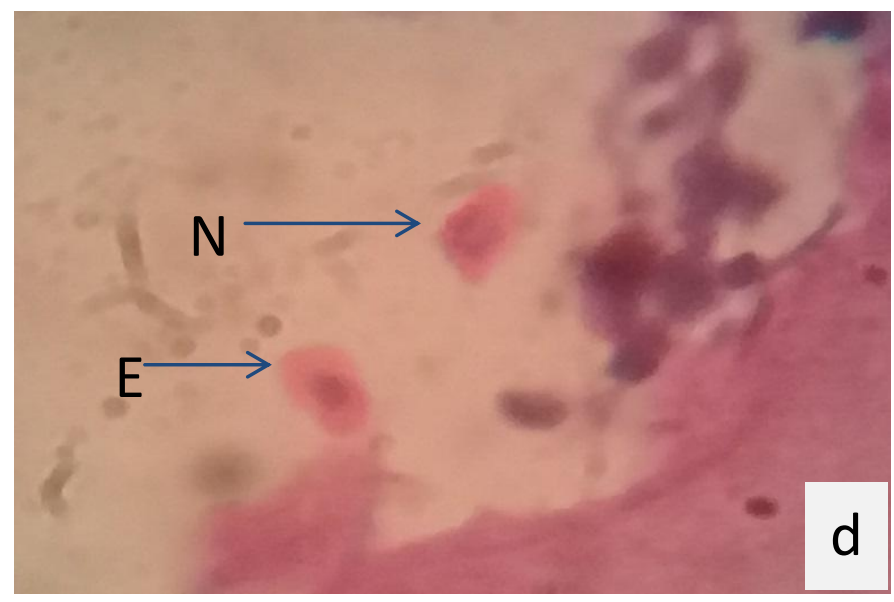

strains of $A$. veroniibiovarsobria (Gashgari and Selim, 2015) were found to be within the range of the present value.

Higher LD $_{50}$ values $\left(2 \times 10^{7}\right.$ CFU/fish $)$ in Anabas testudineus when intramuscularly injected with A. hydrophila (Hossain et al., 2011). This difference could be due to different mode of injection, strain or host studied (Cai et al., 2012).

In conclusion, we confirmed that the present bacteria $A$. veronii strain BLB-01 is highly pathogenic to $C$. batrachus and caused mass mortality in C. batrachus cultured ponds. 


\section{Histopathology}

Histologically, the infected muscle tissue of C. batrachus showed erythrocyte and leukocyte infiltration (ELI) due to bacterial infection (Fig. 6). Similarly lymphocytic, neutrophil infiltration has been observation in the muscle of ulcerated $C$. gariepinus infected with Edwardsiella tarda (Abraham et al., 2015) and Leukocyte infiltration infected with Aeromonas hydrophila (Laith and Najiah, 2013). This observed histopathological changes in the muscle tissue indicated that blood cell movement has happened from within the blood into the diseased or infected tissues to neutralize the pathogenic effect caused A. veronii strain BLB-01.

\section{In vitro antimicrobial susceptibility test}

Antimicrobial susceptibility test showed that the isolated A.veronii strain BLB-01was multi-resistant to most frequently used antimicrobial agents in India such as Cephalothin, Ciprofloxacin, Clarithromycin, Clindamycin, Levofloxacin, Moxifloxacin, Oxacillin, Synercid, Teicoplanin, Vancomycin but sensitive to Chloramphenicol, Fosfomycin, Gentamicin, Neltilmicin, Rifampin of the antibiotic tested (Table 4). The present results also in line with the fact that most of Aeromonas species are susceptible to chloramphenicol (Awan et al., 2009). The present study also supports the fact that most strains of Aeromonas are susceptible to chloramphenicol but resistant to vancomycin, clindamycin in USA (LupiolaGomez et al., 2003). However present findings differ with the findings of Petersen and Dalsgaard (2003) who reported that the Aeromonas strains were resistant against the antibiotic chloramphenicol. It has been a common phenomenon that, the resistant to different antibiotic are variable with respect to area and country, therefore antimicrobial resistance should be performed when the bacterial pathogen are isolated from the samples, in order to avoid the development of serious clinical symptoms and spread of the pathogen in the environment with secretive and excretive products which may ultimate results in therapeutic failures (Cai et al., 2012). In vitro antibiotic sensitivity test had helped us to select susceptive antibiotic to prevent and treat the disease. To negate the harmful effect of antibiotic residue sufficient withdrawal period should be given as applied in the present study. The need of the hour is to go for better management practices (BMP) for the $C$. batrachus so that the culture operation can be sustainable.

\section{Acknowledgements}

The authors thank Dr. W.S. Lakra, the Former Director ICAR- Central Institute of Fisheries Education, Mumbai and the present Director Dr. Gopal Krishna of ICAR-Central Institute of Fisheries Education, Mumbai for providing all the support and facilities required for the study. The authors also thank all the relevant persons who have dedicated time to these experiments.

\section{References}

Abraham T.J., Mallick, P.K. Adikesavalu, H. Banerjee, S. 2015. Pathology of Edwardsiellatarda infection in African catfish, Clariasgariepinus (Burchell 1822), fingerlings. Archives of Polish Fisheries journal, 23.141-148.

APHA, (American Public Health Association) 2005.Standard Methods for the Examination of Water and Wastewater. No: 4500-O C. Winkler Method, Azide Modification, American Public Health Association, 21st Edition. Washington D.C.

Argungu, L.A., Christianus, A. Amin, S.M.N. Daud, S.K. Siraj, S.S. Rahman, M.A. 2013. Asian Catfish Clariasbatrachus 
(Linnaeus, 1758) getting critically endangered. Asian Journal of Animal and Veterinary Advances, 8, 168-176.

Awan, M.B., Maqbool, A. Bari, A. Krovacek, K. 2009. Antibiotic susceptibility profile of Aeromonas spp. isolates from food in Abu Dhabi, United Arab Emirates. New Microbiologica, 32(1), 17-23.

Bauer, A.W., Kirby, W.M. Sherris, J.C. Turck, M. 1966. Antibiotic susceptibility testing by a standardized single disk method.American Journal of Clinical Pathology, 45, 493-496.

Cai, S., Wu, Z. Jian, J. Lu, Y. Tang, J. 2012. Characterization of pathogenic Aeromonas veroniibv. veronii associated with ulcerative syndrome from Chinese longsnout catfish (Leiocassislongirostris Gunther). Brazilian Journal of Microbiology, 43(1), 382-388.

Eissa, I.A.M., Maather El-lamei Mona, Sherif, E. Desuky, Mona, S.Z. Bakry M. 2015. Aeromonas veroniibiovarsobria a causative agent of mass mortalities in cultured nile tilapia in El-Sharkia governorate Egypt. Life Science Journal, 12(5), 90-97.

Gashgari, R.M., and Selim, S.A. 2015. Detection and characterization of antimicrobial resistance and putative virulence genes in Aeromonas veronii biovarsobria isolated from Gilthead Sea Bream (Sparus aurata L.). Foodborne Pathogens and Disease, 12(9), 806-811.

Gong, Q., Gao, S. Shan, X. Guo, W. Meng, Q. Wang, W. Qian, A. 2010. Isolation and identification of pathogenic Aeromonas veronii from Cyprinus carpio. Chinese Journal of preventive veterinary medicine, 32(12), 981-983.

Han, H.J., Taki, T. Kondo, H. Hirono, I. Aoki, T. 2008. Pathogenic potential of a collagenase gene from Aeromonas veronii. Canadian Journal of
Microbiology, 54, 1-10.

Hichman-Brenner, F.W., MacDonald, K.L. Steiqerwalt, A.G. Fanning, G.R. Brenner, D.J., Farmer, J.J. 1987.Aeromonas veronii, a new ornithine decarboxylase-positive species that may cause diarrhea. Journal of Clinical Microbiology, 25, 900-906.

Hossain, M., 2008. Isolation of pathogenic bacteria from the skin ulcerous symptomatic gourami (Colisalalia) through 16S rDNA analysis. University Journal of Zoology Rajshahi University, 27, 21-24.

Hossain, M.F., Rashid, M.M. Sayed, M.A. 2011. Experimental infection of indigenous climbing perch Anabas testudineus with Aeromonas hydrophila bacteria. Progressive Agriculture, 22(1 \& 2), 105-114.

Huang, X., Wang, K. Zong-Jun, D. Geng, Y. Deng, Y. 2010. Identification, isolation and in vitro antimicrobial susceptibility testing of Aeromonas veronii associated with an acute death of Channel Catfish (Ictalurus lunetas) in China. African Journal of Biotechnology, 9(14), 21612164.

Janda, J.M., and Abbott, S.L. 1998. Evolving concepts regarding the genus Aeromonas: an expanding panorama of species, disease presentations, and unanswered questions. Clinical Infectious Diseases, 27, 332-334.

Janda, J.M., and Abbott, S.L. 2010. The genus Aeromonas: Taxonomy, pathogenicity, and infection. Clinical Microbiology Reviews, 23(1), 35-73.

Kong, R.Y.C., Lee, S.K.Y. Law, T.W.F. Law, S.H.W. Wu, R.S.S. 2002.Rapid detection of six types of bacterial pathogens in marine waters by multiplex PCR. Water Research, 36, 2802-2812.

Laith, A.R., and Najiah, M. 2013. Aeromonas hydrophila:

Antimicrobial 
Susceptibility and Histopathology of Isolates from Diseased Catfish, Clarias gariepinus (Burchell). Journal of Aquaculture Research and Development, 5: 215.

Li, L., Du, Z.Z. Sun, X. Shao, X.G. Li, J.G. Zhang, L.X. Wang, Y.M. Wu, Q. 2008. Severe pneumonia caused by Aeromonas veroniibiovarsobria: A case report and review of the literature. Chinese journal of tuberculosis and respiratory diseases, 31, 736-739.

Liu, D., Geng, Y. Wang, K. Chen, D. Huang, X.L. Ou, Y. He, C.L. Zhong, Z.J. Lai W. 2016.Aeromonas veronii infection in cultured channel catfish, ictaluruspunctatus, in southwest China.The Israeli Journal of Aquaculture-Bamidgeh, 67, 1225-1232. Lupiola-Gomez, P.A., Gonzalez-Lama, Z. Tejedor- Junco, M.T. Gonzalez-Martin, M. Martin-Barrasa, J.L. 2003. "Group 1 beta-lactamases of Aeromonas caviae and their resistance to beta-lactam antibiotics."Canadian Journal of Microbiology, 49(1), 207-215.

Ma, Z., Yang, H. Li, T. Luo, L. Gao, J. 2009. Isolation and identification of pathogenic Aeromonas veronii isolated from infected siberian sturgeon (Acipenser baerii). Acta Microbiologica Sinica, 49(10), 1289-1294.

Martinez-Murcia, A., Beaz-Hidalgo, R. Svec, P. Saavedra, M.J. Figueras M.J. Sedlacek, I. 2013.Aeromonas cavernicola sp. nov., isolated from freshwater of a brook in a cavern. Current Microbiology, 66,197-204.

Mookerjee, H.K., and Mazumder, S.R. 1950. Some aspects of the life history of C. batrachus. Proceedings of the Zoological Society of Bengal,3, 71-84.

National Committee for Clinical Laboratory Standards, 2000.Methods for dilution antimicrobial susceptibility tests for bacteria that grow aerobically. NCCLS,
Wayne, PA.

Nawaz, M.S., Sung, K. Khan, S.A. Khan, A.A. Steele, R.S. 2006. Biochemical and molecular characterization of tetracycline-resistant Aeromonas veronii isolates from catfish. Applied and Environmental Microbiology, 72, 64616466.

Paul, P., Adikesavalu, H. Banerjee, S. Abraham, T. J. 2015. Antibiotic Resistant Motile Aeromonads Induced Septicemia In Philippine Catfish Clarias batrachus (Linnaeus, 1758) Fingerlings. Croatian Journal of Fisheries, 73, 170-175.

Petersen, A., and Dalsgaard, A. 2003. "Antimicrobial resistance of intestinal Aeromonas spp. and Enterococcus spp. in fish cultured in integrated broiler-fish farms in Thailand." Aquaculture, 219(1-4), 71-82.

Qin, L., Xu, J. Zhang, X. 2008. Infection with Aeromonas veroniibiovarsobria in Misgurnus anguillicaudatus.Chinese Journal of Zoology, 24(12), 1100-1102.

Reed, L.J., and Muench, H. 1938. A simple method of estimating $50 \%$ endpoints.American Journal of Hygiene, 27, 493-494.

Roberts, M.T., Enoch, D.A. Harris, K.A. Karas, J.A. 2006. Aeromonas veroniibiovarsobria bacteraemia with septic arthritis confirmed by $16 \mathrm{~S}$ rDNA PCR in a immunocompetent adult. Journal of Medical Microbiology, 55, 241-243.

Roberts, R.J., 2012. Fish Pathology, fourth ed. Wiley-Blackwell, UK, P.581.

Santos, J.A., Gonzalez, C.J. Otero, A. GarciaLopez, M.L. 1999. Hemolytic and siderophore production in different Aeromonas species isolated from fish. Applied and environmental microbiology, 65, 5612-5614.

Singh, V., Chaudhary, D.K. Mani, I. 2012.Molecular characterization and 
modeling of secondary structure of $16 \mathrm{~S}$ rRNA from Aeromonas veronii. International Journal of applied biology and Pharmaceutical Technology,3(1), 253-260.

Sreedharan, K., Philip, R. Singh, I.S.B. 2011. Isolation and characterization of virulent Aeromonas veronii from ascetic fluid of oscar Astronotus ocellatus showing signs of infectious dropsy. Diseases of Aquatic Organisms, 94(1), 29-39.

Stackebrandt, E., and Goebel, B. 1994. Taxonomic note: a place for DNA-DNA reassociation and 16S rRNA sequence analysis in the present species definition in bacteriology. International Journal of Systematic and Evolutionary Microbiology, 44, 846-849.

Sun, J., Zhang, X. Gao, X. Jiang, Q. Wen, Y. Lin, L. 2016. Characterization of Virulence Properties of Aeromonas veronii Isolated from Diseased Gibel Carp (Carassius gibelio). International journal of molecular science, 17, 496.

Thomas, J., Jerobin, J. Seelan, T.S.J. Thanigaivel, S. Vijayakumar, S. Mukherjee, A. Chandrasekaran, N. 2013. Studies on pathogenecity of Aeromonas salmonicida in catfish Clariasbatrachus and control measures by neem nanoemulsion. Aquaculture, 396-399,
71-75.

Vos, P., Garrity, G. Jones, D. Krieg, N.R. Ludwig, W. Rainey, F.A. Schleifer, K. Whiteman, W. 2009. Bergey's Manual of Systematic Bacteriology: Volume 3: The Firmicutes (Bergey's Manual of Systematic Bacteriology, 3rd Edition, Springer-Verlag.

Wang, J.T., Fang, C.T. Hsueh, P.R. Chang, S.C. Luh, K.T. 2000. Spontaneous bacterial empyema caused by Aeromonas veronii biotypesobria. Diagnostic Microbiology and Infectious Diseases, 37, 271-273.

Wilmsen, H.U., Pattus, F. Buckley, J.T. 1990. Aerolysin, a haemolysin from Aeromonas hydrophila, forms voltage gated channels in planar lipid bilayers. The journal of membrane biology, 115, 71-81.

Wong, C.Y.F., Heuzenroeder, M.W. Flower, R.L.P. 1998. Inactivation of two haemolytic toxin genes in Aeromonas hydrophila attenuates virulence in a suckling mouse model. Microbiology, 144, 291-298.

Zhang, D.C., Liu, H.C. Zhou Y.G. Schinner, F. Margesin, R. 2011.Pseudomonas bauzanensis sp. Nov., isolated from soil. International Journal of Systematic and Evolutionary Microbiology, 61, 2333-2337.

\section{How to cite this article:}

Arun Sharma, Thongam Ibemcha Chanu, Muralidhar P. Ande, P.P. Suresh Babu, Karthireddy Syamala, Pothu Srinivasa Rao, Ashutosh D. Deo and Shrinivas Jahageerdar.2017. Virulent Aeromonas veronii Strain BLB-01 Associated with Mass Mortality of Clarias batrachus (Linnaeus, 1758). Int.J.Curr.Microbiol.App.Sci. 6(8): 3668-3681. doi: https://doi.org/10.20546/ijcmas.2017.608.444 